\title{
Formulation and Application of Whey-Protein Based Coatings for Improved Paperboard Properties
}

\author{
Mona A. Nassar ${ }^{\#}$ and Y. R. Hassan \\ Packaging and Packing Department, National Research \\ Centre, Giza, Egypt.
}

\begin{abstract}
A N ECONOMICALLY acceptable approach to improve water barrier property of paperboard was established. This approach is based on preparation and application of biodegradable- based polymeric coatings onto paperboard surfaces composed of a combination of commercial whey protein and polyvinyl alcohol. Blending of PVA solution with whey protein solution led to improvement in the viscosity of the resultant formula. Low molecular weight polyol (glycerol) was also used as a plasticizer in the formula. Films containing different ratios of whey protein and PVA were prepared and characterized by FTIR. SEM was used to investigate the surface morphology of the prepared films as well as the coated paperboard. It was noticed that film surfaces containing large percent whey protein were rough. Mechanical tests of films and coated paperboard show positive results. Water permeability of coated paperboard by biopolymer blend was improved by approximately $60 \%$ compared to uncoated substrate. This work has also explored the recycling potential of barrier-coated boards as an alternative option to disposal in a landfill.
\end{abstract}

Keywords: Coating, Paperboard, Whey protein and Water permeability.

The preparation process of blending two or more polymers has been considered to be one of the most promising methods to achieve new materials with good performance as compared with their chemical modification. Combining synthetic polymers with natural materials provides ways to reduce costs and offers benefits from the combined properties. The association by blending is an interesting way to overcome some weaknesses of polymers such as poor mechanical properties and low degradability. Blending synthetic polymers with natural polymers can obtain new polymeric materials with superior performance while reducing the amount of chemical in use ${ }^{(1)}$. Interestingly, it has been found that blending of, poly(vinyl alcohol) (PVA), with natural polymers forms biodegradable composites. PVA/natural polymer blends have promising industrial applications in many fields because of their biodegradability, biocompatibility, chemical resistance and excellent physical properties ${ }^{(2-4)}$.

\#Monanassar_65@yahoo.com 
A variety of polymers from renewable sources, e.g. polysaccharides, proteins, lipids and their composites, derived from plant and animal feedstock, have thus been investigated toward development of edible/biodegradable, nontoxic packaging materials that might replace synthetic polymers ${ }^{(5,6)}$.

In particular, various whey protein products have been developed in recent decades including whey protein concentrates (WPC) produced by ultrafiltration (UF), with protein contents ranging in $35-80 \%(\mathrm{w} / \mathrm{w})$ on a dry basis, as well as whey protein isolates (WPI) produced by ion-exchange and subsequent UF, with protein contents above $90 \%(\mathrm{w} / \mathrm{w})^{(7)}$. Beside their distinct protein contents, WPI and WPC differ in the levels of such other constituents as lipids, minerals and lactose. These differences may influence the intermolecular bonds in the manufactured films and consequently their barrier, mechanical and thermal properties $^{(8)}$.

Paperboard belongs to a group of products, which has the advantage of being renewable, commonly available and cost efficient with excellent potential for use as a base substrate in numerous applications. In addition, it is possible to adjust the properties of the intended end-use by simply choosing appropriate manufacturing conditions ${ }^{(9,10)}$. At the same time, it is necessary to have a good understanding of the substrate properties as well as the manufacturing methods. Therefore, the development procedure requires support from analytical tools and material characterization. This is even more important at the interfacial regions where paper packaging is still used substantially in food packaging applications. For instance, packaging materials must be able to protect or hold food while offering moisture or grease barrier properties ${ }^{(11)}$. To a limited extent packaging paper usually has poor gas, moisture and grease resistance. As a consequence, it is often coated to improve its barrier properties especially to water vapor, oxygen, aromas and grease by hydrophobic materials such as paraffin wax and polyethylene. However, the content of the polyethylene and paraffin wax of packaging materials makes it difficult to separate, recycle or compost them after use ${ }^{(12,13)}$.In an effort to produce more environmentally friendly materials, renewable and biodegradable biopolymers have been utilized as paper coating substances.

The aim of this work is to prepare biodegradable coatings based on commercial whey protein and PVA for paperboard. Treatment of paperboard surface with the prepared polymeric is meant to improve the water permeability and the mechanical properties of paperboard intended for food packaging applications.

\section{Materials and Methods}

Materials

Commercial whey protein containing $12.88 \%$ protein and poly vinyl alcohol (degree of polymerization1700:1800), obtained from Qualikem Fine Chemicals Pvt. Ltd. New Delhi were used as biodegradable coating materials. Unbleached 
paperboard of basis weight $150 \mathrm{~g} / \mathrm{m}^{2}$ represents the substrate. Low molecular weight polyol glycerol (99.7\%) was supplied by Elgomhoria Company. Analytical grade sodium hydroxide. ( $\mathrm{NaOH})$ pellets obtained from El Nasr pharmaceutical Chimecals Co. were used to prepare $0.1 \mathrm{M}$ solution at room temperature.

\section{Determination of protein percent for whey protein}

Nitrogen content of the whey protein was determined using Kjeldahl distillation units (AOAC). The protein percent, in commercial whey protein powder, was calculated applying the following formula: ${ }^{(14)}$

$$
\text { Protein } \%=\mathrm{N} \times 6.25
$$

\section{Film preparation}

Fabrication of WP/PVA films was based on a solution casting and evaporation method. The total solid content forming film was $10 \% \mathrm{w} / \mathrm{w}$ containing four levels of WP:PVA, 100\%:0\%, 50\%:50\%, 25:75\% and 75:25. Glycerol was added at $2 \%$ level (w/w) on total weight basis to plasticize the films.

Film-forming solutions were prepared by slow dissolution of WP powder in distilled water under magnetic stirring at $70^{\circ} \mathrm{C}$ for $10 \mathrm{~min}$ and adjusting the $\mathrm{pH}$ of solution at 7.0 with $0.1 \mathrm{M} \mathrm{NaOH}$.

PVA aqueous solution was prepared by stir-heating in a water bath at $90{ }^{\circ} \mathrm{C}$ for $60 \mathrm{~min}$. Mixtures, including the prepared WP solutions, with various weight ratios of PVA water solution and glycerol, were made as the film fabrication resins. The $\mathrm{pH}$ of the resins was again adjusted to $\mathrm{pH} 7.0$ with $0.1 \mathrm{M} \mathrm{NaOH}$ solution followed by heating at $80^{\circ} \mathrm{C}$ with continuous stirring for $30 \mathrm{~min}$. The solutions obtained were poured onto Teflon-coated plates, where the amount of each film forming solution poured was the same $(100 \mathrm{ml})$. The spread solutions were allowed to dry at $70^{\circ} \mathrm{C}$ for $6 \mathrm{hr}$. Once formed, the films were peeled off and conditioned in a controlled temperature and humidity storage room, for at least $72 \mathrm{hr}$ prior to testing ${ }^{(15)}$.

Viscosity of coating solution

Viscosity was tested by a Brookfield DV-III viscometer (ULTRA PROGRAMMABLE RHEOMETER) with spindles No. 21, 27 at the speeds of 80,250 and $150 \mathrm{rpm}$ and the value of viscosity was taken at $20 \mathrm{~s}$.

\section{Coating application}

Unbleached paperboard (basis weight, $150 \mathrm{~g} / \mathrm{m}^{2}$; thickness $0.565 \mathrm{~mm}$ ) was used as substrates to apply the hybrid polymer coatings. The biodegradable coatings were applied from prepared aqueous plasticized PVA/WP blends on one face using roll coater. The applied coatings were dried under hot-air oven drying for $5 \mathrm{~min}$ at $35^{\circ} \mathrm{C}$. The coated paperboards were subsequently conditioned for at least $24 \mathrm{hr}$ at $23{ }^{\circ} \mathrm{C}$ and $50 \%$ relative humidity before subsequent measurements 
were performed.

Test series

FT-IR of whey protein powder,coated paperboard and WP/PVA blend film was performed using a Thermo-Nicolet Model 670 Instrument (Thermo Electron, Inc, Madison, WI). Film thickness was measured using micrometer model Chuan-Lu at three random positions. Film morphology was investigated using scanning electron microscopy (SEM). Water permeability at WG $100 \mathrm{~mm}$ of uncoated and one surface coated carton is determined according to BS 6906 part III Tayousiki Japan.

The mechanical properties of blend films and coated paperboard were evaluated with a 3369 Instron Universal Testing Machine, using a load cell of $\pm 0.1000 \mathrm{~N}$. Paper strips of $15 \mathrm{~mm}$ width were clamped with an initial grip separation of $50 \mathrm{~mm}$ and elongated with a cross-head speed of $50 \mathrm{~mm} / \mathrm{min}$ until fracture.

\section{Results and Discussion}

According to economic view, waste WP was used in this study in form of composites with poly vinyl alcohol and glycerol.

The $\mathrm{pH}$ of WP/PVA/glycerol blends was adjusted at 7 by $0.1 \mathrm{M} \mathrm{NaOH}$ solution after addition of glycerol that slightly reduces the $\mathrm{pH}$ of the mixture. Stirring the mixture at $80^{\circ} \mathrm{C}$ for $30 \mathrm{~min}$ was found to be essential to allow the formation of intermolecular bonds, which assist in establishment of a crosslinked polymeric network structure. Such a process is also necessary to obtain flexible film that can retain their structural integrity under high moisture environments (16)

The thicknesses of the prepared films were $0.25 \mathrm{~mm}$ at $25 \%$ whey protein, $0.26 \mathrm{~mm}$ at $50 \%$ whey protein and $0.37 \mathrm{~mm}$ at $75 \%$ whey protein, respectively. It was noticed that films containing large ratios of commercial WP appeared to be thicker.

Effect of PVA concentration on the viscosity of the coating solutions

The effect of WP and PVA contents on the viscosity was studied (Table 1). The results showed that as the concentrations of PVA increases, the viscosity of the obtained coating solution increases well. In contrast, the concentration of WP had no effect on viscosity. For example samples composed of 50\% WP, the viscosity did not significantly increase; $109 \mathrm{cP}$. On the other hand, raising the PVA concentration from $50 \%$ to $75 \%$ resulted in a significant increase in the viscosity. Moreover, the addition of PVA into whey protein successfully increased the viscosity ${ }^{(17)}$ indicating that interactions occurs between these two polymers when their solutions are blended at $\mathrm{pH}$ 7.0. Thus, the viscosimetry method can be used to investigate polymer-polymer interactions and for assessment of the miscibility between natural and synthetic polymers ${ }^{(18)}$.

Egypt. J. Chem. 56, No.3(2013) 
TABLE 1. Effect of PVA/WP ratio on the viscosity of PVA/WP/glycerol composites.

\begin{tabular}{|l|c|c|c|}
\hline Specimen & Viscosity,cP & Torque \% & Speed, rpm \\
\hline 75\% PVA:25\% WP & 356.7 & 11.3 & 80 \\
\hline 50\% PVA: 50\% WP & 109 & 11 & 250 \\
\hline 25\%PVA:75\% WP & 34 & 10.5 & 150 \\
\hline 100\% WP & 6 & 3.2 & 250 \\
\hline
\end{tabular}

Spindle type changed according to related viscosity.

Film tensile properties

Data corresponding to the tensile properties of WP/PVA glycerol films, with different levels of WP, are shown in Fig.1. WP film containing 0\% PVA was very poor and brittle. Raising the PVA\% to $25 \%$ led to an increase in tensile strength of the film from 0 to $1.71 \mathrm{~N} / \mathrm{mm}^{2}$. Indeed, PVA improves the flexibility and decreases the brittleness of whey protein based film. This is most likely due to the decrease in intermolecular interaction between proteins molecules resulted from the dispersed PVA molecules in the film matrix. On the other hand, film consists of 25\%WP: $75 \%$ PVA has significantly higher values of tensile strength (TS) and elongation at break (EB) than those for WP films with the lower PVA contents. Hence, film made from $25 \% \mathrm{WP}$ : $75 \%$ PVA is stronger and more flexible than that made of WP with lower PVA content, owing to higher mechanical resistance (i.e. higher TS) and higher extensibility of PVA.

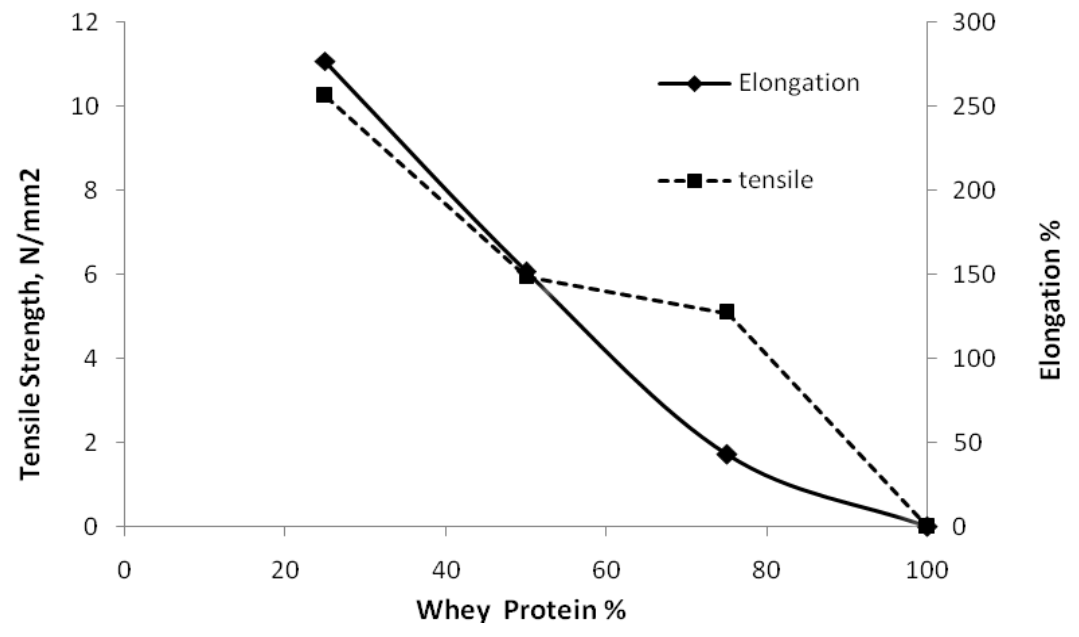

Fig. 1. Tensile properties of WP/PVA/ glycerol films.

Also, the presence of glycerol increases film elasticity and elongation because it constrains establishment of hydrogen bonds between the protein chains and 
PVA molecules thus increasing intermolecular spacing, and therefore chain mobility ${ }^{(19)}$.

\section{Morphology of films}

Figure 2 shows surface morphology of WP/PVA/glycerol films. All film types showed dense structures and rough surfaces. This means that blending with PVA cannot absolutely eliminate structural defects. The film containing large amount of PVA displays smooth parts more than other films. However, films containing large amount of WP, $50 \%$ and $75 \%$ become more, irregular and rough compared to those of lower WP ratios.

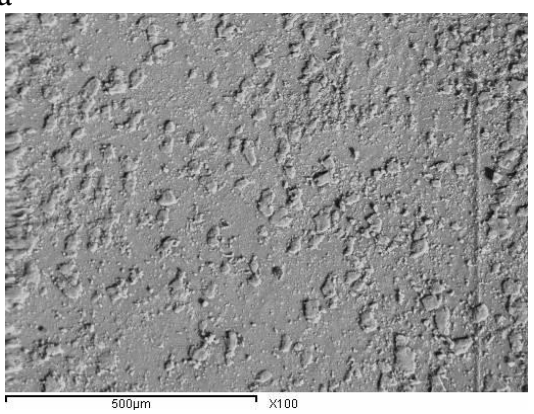

b

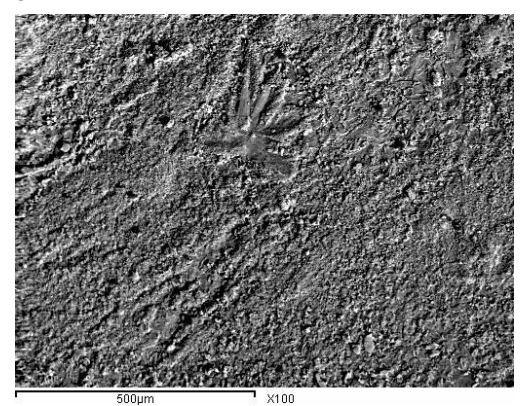

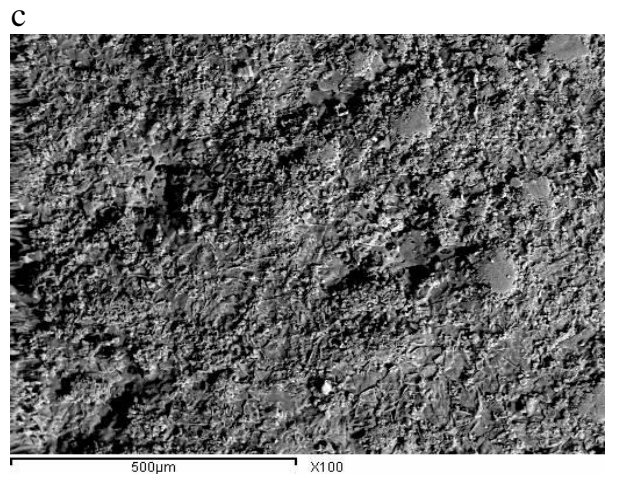

Fig. 2. SEM of WP/PVA/glycerol films (a)25\% WP: 75\% PVA, (b)50\% WP:50\% PVA, (c) 75\% WP: 25\% PVA

Properties of coated paper board

The effective coating thickness is difficult to measure because of topographical variations in the paperboard surface, but values are within the range of $0.5 \mathrm{~mm}$ thereby covering the macro-porosities over the paperboard surface. The water permeability measurement used in this study is based on the flow rate of water ejected at a given pressure between 2 and $1000 \mathrm{kPa}{ }^{(20)}$ through a nozzle pressed against one surface of the sheet material whose permeability is

Egypt. J. Chem. 56, No.3(2013) 
to be measured. From Table 2, the values of water permeability of coated paperboard are significantly lower than those of uncoated paperboard. The water penetration and absorption into the paper are also largely dependent on the homogeneity and the internal structure of the coating. Coating solution consists of 25\%:75\% WP:PVA gives the least water permeability, i.e. $3.97 \mathrm{~L} / \mathrm{m}^{2}$. $\mathrm{min}$, owing to formation of hydrogen bonds between -OH of PVA, - $\mathrm{NH} 2$ of whey protein and $-\mathrm{OH}$ of cellulose which may inhibit diffusion of water molecules. Large percent of synthetic polymer filled pores and minimize the porosity and the hydrophilic property of natural polymers thus decreasing flow rate of water ${ }^{(21)}$.

TABLE 2. Mechanical properties and water permeability of uncoated and PVA/WP/glycerol coated paperboard.

\begin{tabular}{|l|c|c|c|}
\hline Sample & Load ,N & Extension, $\mathbf{m m}$ & $\begin{array}{c}\text { Water } \\
\text { permeability, } \\
\text { L/m } \mathbf{m}^{\mathbf{2}} \mathbf{m i n}\end{array}$ \\
\hline Blank & 36.095 & 2.72 & 10.08 \\
\hline 50\% WP : 50\%PVA coating & 55.6 & 3.315 & 6.58 \\
\hline 75\% WP :25\%PVA coating & 46.005 & 3.08 & 5.38 \\
\hline 25\%WP: 75\% PVA coating & 57.535 & 4.345 & 3.97 \\
\hline
\end{tabular}

Infrared characterization

Fourier transform infrared (FTIR) spectroscopy has been applied to investigate specific molecular bonding interactions in polymer blends. When two polymers are in separate and distinct phases (completely immiscible), it can be assumed that the two components do not interact in IR spectral terms (except perhaps at the interface of the two phases). In that case, the spectrum of the blend reflects the appropriate addition of the IR spectrum of the two individual components. However in case of miscible or partially miscible polymer blends, the IR spectrum may show formation of new bands as a result of miscibility; and disappearance of some component bands. Shifts in specific bands would give information on the switches from component specific bonds to the bonds between components ${ }^{(22)}$.

The FT-IR spectrum of whey protein shows, a strong band at $\approx 3380 \mathrm{~cm}^{-1}$ due to amine NH symmetric stretching vibration (Fig.3a). The peak at $\approx 2927 \mathrm{~cm}^{-1}$ is typical C-H vibration, while band at $\approx 1430 \mathrm{~cm}^{-1}$ is due to amino acids functionality. Band at $\approx 1655 \mathrm{~cm}^{-1}$ indicates the presence of $\mathrm{C}=\mathrm{O}$, while the broad peak at $\approx 1090 \mathrm{~cm}^{-1}$ indicates $\mathrm{C}-\mathrm{O}$ stretching vibration.

In Fig. 3b, which represents the composites film, the characteristic peaks of PVA appear together with the bands belong to whey protein at $3388 \mathrm{~cm}^{-1}$ in addition to broad band at $3760 \mathrm{~cm}^{-1}$ which could be related to free or unbounded $-\mathrm{OH}$ group. 


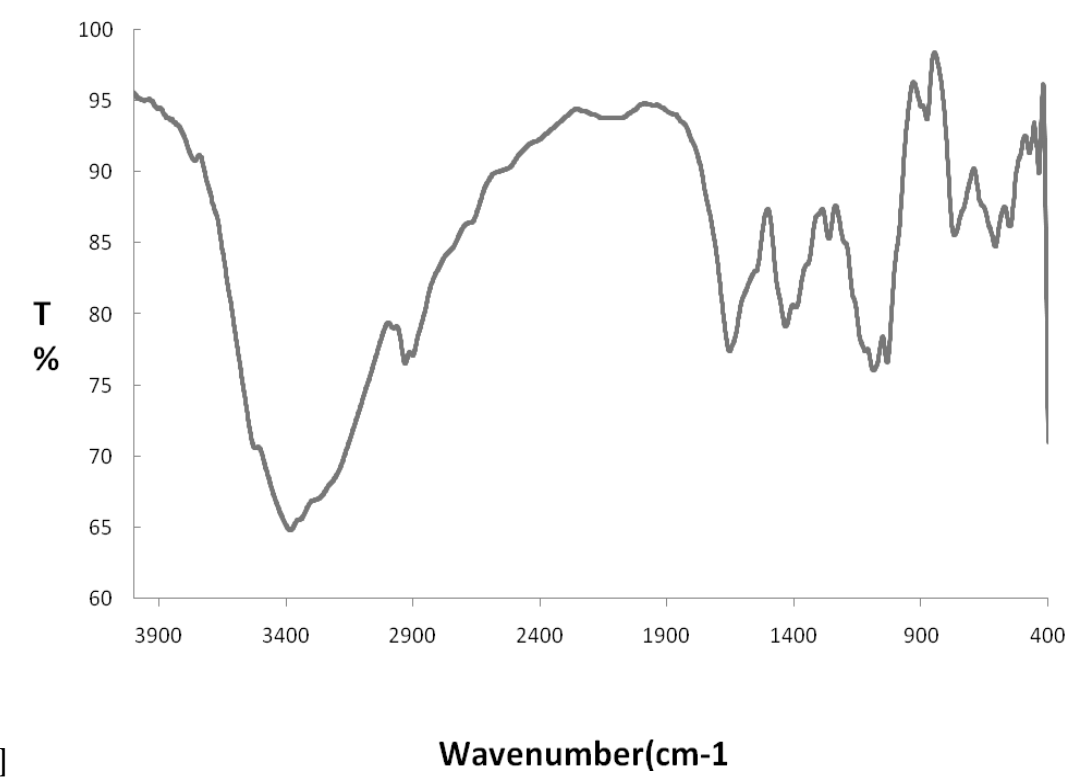

Fig.3a.FTIR spectrum of whey protein.

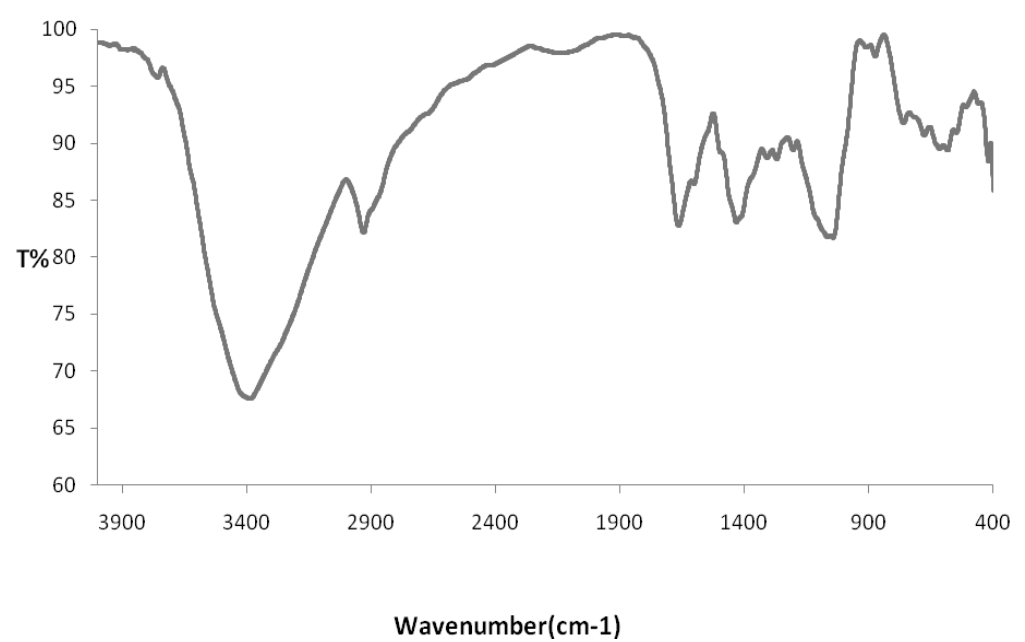

Fig. 3b. FTIR spectrum of WP/PVA/glycerol blend.

Egypt. J. Chem. 56, No.3(2013) 


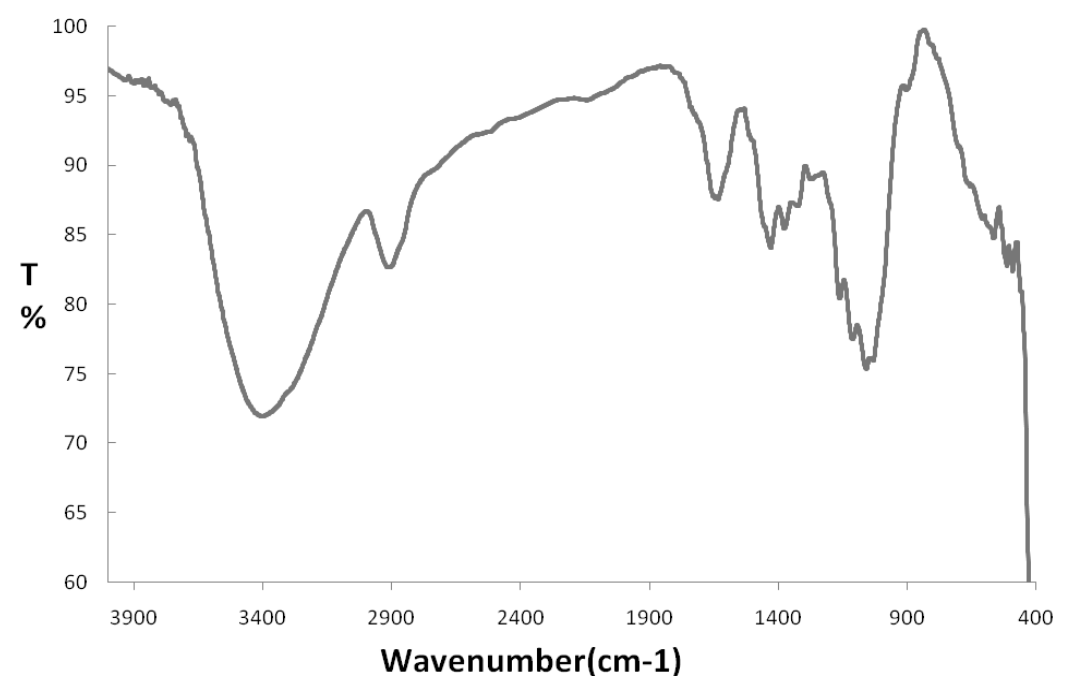

Fig. 3c. FTIR spectrum of paperboard coated by WP/PVA/glycerol blend .

Several studies on proteins concerning this spectral region showed that the band of NH stretching mode is generally at $3254 \mathrm{~cm}^{-1(23)}$. There is therefore a displacement of the band that could be due, in our case, to the presence of other components in the biofilm formulation, especially glycerol and PVA (with a large amount of hydroxyl groups). It is clear that band of amino acids at1432 $\mathrm{cm}^{-1}$ is also found.

FTIR spectrum of paperboard coated with WP/PVA/glycerol, Fig. 3c shows a peak located at $1630 \mathrm{~cm}^{-1}$ attributable to amide vibrational mode because of the presence of the protein coating. The same peaks may also be ascribed to the presence of end amino acids-asymmetric and symmetric vibrations of the- $\mathrm{NH}_{3}{ }^{+}$ groups $^{(24)}$. However, the vibration modes of cellulose are still visible. Band at $3860 \mathrm{~cm}^{-1}$ is attributed to free and bound $\mathrm{O}-\mathrm{H}$ and N-H groups. Abroad band at 3406 $\mathrm{cm}^{-1}$ may indicate an overlap between $-\mathrm{OH}$ of cellulose, $-\mathrm{NH}$ of $\mathrm{WP}$ and $-\mathrm{OH}$ of PVA. The typical vibration modes of cellulose namely, $v(\mathrm{OH})$ at $\approx 3300 \mathrm{~cm}^{-1}$, $v\left(\mathrm{CH}_{2}\right)$ at $2900 \mathrm{~cm}^{-1}, \delta\left(\mathrm{CH}_{2}\right)$ at $1429 \mathrm{~cm}^{-1}, \delta(\mathrm{CH})$ at $1376 \mathrm{~cm}^{-1}, v(\mathrm{C}-\mathrm{C})$ at 1204 $\mathrm{cm}^{-1}$ are well detectable.

\section{Conclusion}

Commercial whey protein containing $12.88 \%$ protein was blended with PVA in the presence of (glycerol) as a plasticizer. Film made from 25\%WP: $75 \%$ PVA was found to be stronger and more flexible than those made from WP with lower PVA contents, owing to higher mechanical resistance (i.e. higher TS) and higher extensibility of PVA. Coating paperboard with blended polymers on one face improved the mechanical properties and the water permeability compared to the uncoated paperboard. SEM was used to investigate the surface morphology of 
WP/PVA/glycerol films, indicating that all film types display dense structures and rough surfaces.

\section{References}

1. Doherty, W.O.S., Mousanioum, P. and Fellows, C.M., Value adding to cellulosic ethanol: lignin polymers. Industrial Crops and Products, 33, 259- 276 (2011).

2. Yeh, J.T., Yang, M.C., Wu, C.J., Wu, X. and Wu, C.S., Study on the crystallization kinetic and characterization of poly (lactic acid) and poly(vinyl alcohol) blends. Polymer-plastics Technology and Engineerin, 47, 1289-1296 (2008).

3. Araujo, M.A., Cunha, A.M. and Mota, M., Enzymatic degradation of starch thermoplastic blends using samples of different thickness. The Journal of Materials Science: Materials in Medicine, 20, 607-614 (2009).

4. Barreto, P. L. M., Pires, A. T. N. and Soldi, V.,Thermal degradation of edible films based on milk proteins and gelatin in inert atmosphere. Polymer Degradation and Stability, 79, 147-152 (2003).

5. Su, R., Su, J.X., Wang, K., Chen, D.Q., Yang, C.Y. and Fu, Q., Phase behavior and properties of polyvinyl alcohol/gelatin blends with novel $\mathrm{pH}$-dependence. Journal of Polymer Science, B 47, 239-247(2009).

6. Kester, J.J. and Fennema, O.R., Edible films and coatings. A review. Food Technology, 40, 47-59(1986).

7. Krochta, J. M. and de Mulder-Johnston, C. D., Edible and biodegradable polymer films: challenges and opportunities. Food Technology, 51, 61-74(1997).

8. Mulvihill, D.M. and Ennis, M.P., Functional milk proteins: Production and utilization. In: P.F. Fox and P.L.H. McSweeney (Ed.) Advanced Dairy Chemistry: Volume 1: Proteins. $3^{\text {rd }}$ ed. New York, NY: Kluwer Academic; 1175-1228 (2003).

9. Khwaldia, K., Perez, C., Banon, S., Desobry, S. and Hardy, J., Milk proteins for edible films and coatings. Critical Reviews in Food Science and Nutrition, 44(4), 239251(2004).

10. Teisala, H., Tuominen, M., Aromaa, M., Makela, J.M., Stepien, M., Saarinen, J.J., Toivakka, M. and Kuusipalo, Development of superhydrophobic coating on paperboard surface using the liquid flame spray. Surface \& Coatings Technology, 205, 436-445(2010).

11.Yoo, S., Lau, S. and Krochta J. M., grease penetration and browning resistance of pulpboard and paperboard coated with whey protein. Packaging Technology and Science, 259-270 (2012).

12. Kukiatikulchai, D., Effect of coating modified starch and sizing agents on properties of Kraft liner in cold storage application. Master Thesis. Kasetsart University.

Egypt. J. Chem. 56, No.3(2013) 
(2007).

13. Ottenio, D. and Escabasse, J. and Podd, B., Paper and Board for Food Packaging Applications. In : International life science institute. Prepared under the responsibility of the ILSI Europe Packaging Material Task Force. Brussels: ILSI Press, 5-24 (2004).

14. Beebse Jones, D., Factor for converting percentage of nitrogen in food and feeds into percentages of proteins, Principal Chemist. Protein and Nutrtian Division, Chemical and Technological Research, Bureau of Chemistry and Soils.

15. Le Tien, C., Letendre M., Ispas-Szabo, P., Mateescu, M. A., Delmas-Patterson, G., Yu, H. L. and Lacroix, M., Development of biodegradable films from whey proteins by cross-linking and entrapment in cellulose. Journal of Agricultural and Food Chemistry, 48, 5566-5575 (2000).

16. Wang, G., Zhang, T., Ahmad, S., Cheng, J. and Guo, M., Physicochemical and adhesive properties, microstructure and storage stability of whey protein-based paper glue. International Journal of Adhesion \& Adhesives, 41, 198-205 (2013).

17. Sionkowska, A., Current research on the blends of natural and synthetic polymers as new biomaterials: Review Progress in Polymer Science, 36,1254- 1276 (2011).

18. Pulp and Paper Research Institute of Canada17- Ivan I. Pikulik Patent number: 4880499 (1987).

19. Schuman, T., Wikstro, M. and Rigdahl, M., Coating of surface-modified papers with poly(vinyl alcohol). Surface and Coatings Technology, 183, 96-105 (2004) .

20. Sionkowska, A., Skopinska, J. and Wisniewski, M., Collagen synthetic polymer interactions in solution and thin films. Journal of Molecular Liquids,145,135138(2009).

21. Kher, A. , Udabage, P. , McKinnon, I. , McNaughton, D. and Augustin, M. A. , FTIR investigation of spray-dried milk protein concentrate powders. Vibrational Spectroscopy, 44, 375-381(2007).

22. Bandekar, J., Amide modes and protein conformation. Biochimica et Biophysica Acta, 1120, 123-143(1992).

23. Habeger, C. and Coffin, D., Accelerated creep mechanics: parts I and II, Fourth International Symposium on Moisture and Creep Effects on Paper, Board and Containers, EFPG, France (1999).

24. Socrates, G., ( $3^{\text {rd }}$ ed)John Wiley \& Sons, Inc, Oxford (UK) (2004).

(Received 15/5/2013; accepted 3/10/2013)

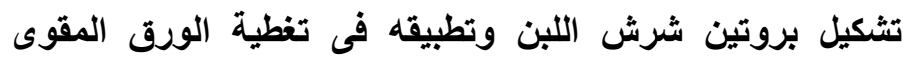

Egypt. J. Chem. 56, No.3 (2013) 


\title{
لتحسين خواصه
}

\author{
منى نصار ويوسف حسن
}

قسم التغليف والتعبئة ــ المركز القومى للبحوث ــ الجيزة ـ مصر.

تهدف هذه الدر اسـة لتحسين خاصية نفاذيـة المـاء للورق المقوى(الكرتون) بطريقة

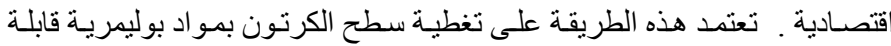

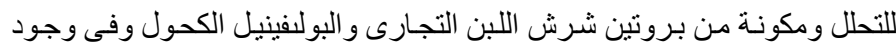

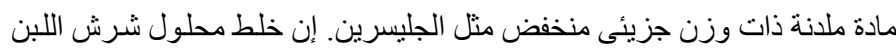

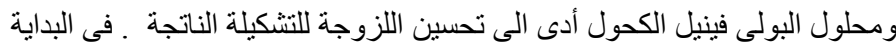

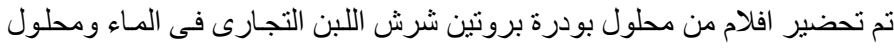

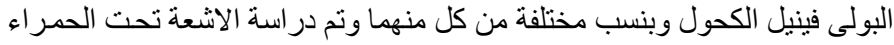

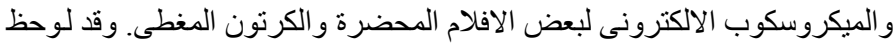

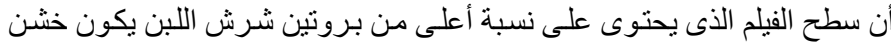

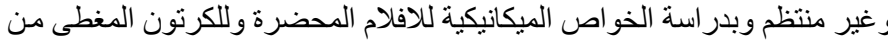

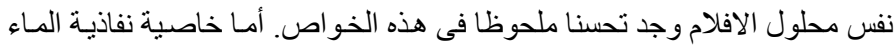

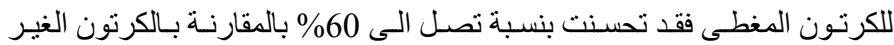

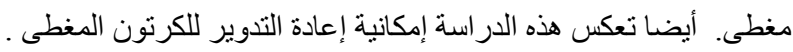

